\title{
Association between nonsteroidal anti-inflammatory drugs use and risk of central nervous system tumors: a dose-response meta analysis
}

\author{
Tao Zhang ${ }^{1, *}$, Xiaowen Yang ${ }^{2, *}$, Pei Liu ${ }^{3}$, Jianrui Zhou ${ }^{4}$, Jie Luo ${ }^{1}$, Hui Wang ${ }^{1}$, Anrong \\ $\mathbf{L i}^{1}$ and $\mathbf{Y i} \mathbf{Z h o u}^{1}$ \\ 1Department of Neurosurgery, Taihe Hospital, Hubei University of Medicine, Shiyan, Hubei, 442000, China \\ ${ }^{2}$ Department of Clinical Laboratory, Taihe Hospital, Hubei University of Medicine, Shiyan, Hubei, 442000, China \\ ${ }^{3}$ Department of Dermatology, Taihe Hospital, Hubei University of Medicine, Shiyan, Hubei, 442000, China \\ ${ }^{4}$ Department of Rehabilitation Medicine, Taihe Hospital, Hubei University of Medicine, Shiyan, Hubei, 442000, China \\ "These authors contributed equally to this work and are co-first authors
}

Correspondence to: Tao Zhang, email: ta0_zhang@sina.com

Keywords: central nervous system tumors, nonsteroidal anti-inflammatory drugs, dose-response relationship, meta analysis

Received: July 31, $2017 \quad$ Accepted: September 23, $2017 \quad$ Published: October 11, 2017

Copyright: Zhang et al. This is an open-access article distributed under the terms of the Creative Commons Attribution License 3.0 (CC BY 3.0), which permits unrestricted use, distribution, and reproduction in any medium, provided the original author and source are credited.

\section{ABSTRACT}

Although studies have examined the association between nonsteroidal antiinflammatory drugs (NSAIDs) use and central nervous system (CNS) tumors risk, the results are inconclusive. Here, we conducted a dose-response meta-analysis in order to investigate the correlation between NSAIDs use and CNS tumors risk. Up to July 2017, 12 studies were included in current meta-analysis. NSAIDs use was significantly associated with a lower risk of CNS tumors. Furthermore, non-aspirin NSAIDs or aspirin use are significantly associated with a lower risk of CNS tumors. Additionally, NSAIDs use was associated with significantly a lower risk of glioma, glioblastoma but not meningioma. Subgroup analysis showed consistent findings. Furthermore, a significant dose-response relationship was observed between NSAIDs use and CNS tumors risk. Increasing cumulative 100 defined daily dose of NSAIDs use was associated with a $5 \%$ decrement of CNS tumors risk, increasing NSAIDs or non-aspirin NSAIDs or aspirin use (per 3 prescriptions increment) was associated with a $7 \%, 7 \%, 10 \%$ decrement of CNS tumors risk, increasing per 2 year of duration of NSAIDs or non-aspirin NSAIDs or aspirin use was associated with a $6 \%, 8 \%, 6 \%$ decrement of CNS tumors risk. Considering these promising results, NSAIDs use might provide helpful for reducing CNS tumors risk. Large sample size and different ethnic population are warranted to validate this association.

\section{INTRODUCTION}

Central nervous system (CNS) tumors are the second leading cause of death from neurological diseases worldwide, and costs on patients, caregivers and society [1]. Survival chances have improved gradually over the last 30 years but remain poor compared to many other cancers, and $30 \%$ glioma survived to one year and $15 \%$ glioma survived to five years of patients after diagnosis in adults $[2,3]$. These data reveal the poor prognosis of CNS tumors, and thus to prevent the occurrence of CNS tumors is essential. The etiology of CNS tumors involves both genetic and environmental factors. Compared with many other cancers, there are only a few identified risk factors for glioma, including increasing age, male, rare genetic syndrome, and high levels of ionizing radiation [4]. Meanwhile, previous studies investigating have showed nonsteroidal anti-inflammatory drugs (NSAIDs) have a chemopreventive potential in the CNS tumors in vitro and in vivo [5].

NSAIDs are a non-steroidal anti-inflammatory drugs, including aspirin, acetaminophen, indomethacin, 
naproxen, diclofenac, ibuprofen, nimesulide, rofecoxib and celecoxib. The main function of NSAIDs is anti-inflammatory, antirheumatic, relieve pain and anticoagulation [6, 7]. At present, NSAIDs is one of the most widely used drugs in the world. About 30 million people use it every day around the world. As people using NSAIDs increases, clinicians, pharmacists, patients, and society and governments pay more attention to the safety of these drugs.

Previous studies have examined the relationship between NSAIDs use and risk of colorectal cancer [8], stomach cancer [9], prostate cancer [10] and breast cancer [11], have found that NSAIDs use is significantly reduce cancer risk. Even though some studies supported NSAIDs use significantly decrease the risk of CNS tumors [12-23]. However, the result remains controversial. Additionally, no study to quantitative assessed NSAIDs use in relation to CNS tumors. Thus, we performed this dose-response meta-analysis to clarify and quantitative assessed the correlation between NSAIDs use and CNS tumors risk.

\section{RESULTS}

\section{Literature search results}

Figure 1 shows literature research and selection. A total of 2215 studies from PubMed and 2547 studies from Embase. After exclusion of duplicates and studies that did not fulfill the inclusion criteria, 12 studies were chosen, and the data were extracted. These studies were published update to July 2017.

\section{Study characteristics}

The characteristics of the included studies of NSAIDs use and CNS tumors risk are shown in the Table 1 and 2. Results in different subgroups were treated as two separate reports. Finally, thirty-three independent reports from twelve studies investigated the association between NSAIDs use and CNS tumors risk. Among the selected reports, twenty-two reports investigated the association between non-aspirin NSAIDs use and CNS tumors risk, eleven reports investigated the association between aspirin use and CNS tumors risk. A total of 667085 participants with 19394 incident cases from three countries were included in this meta-analysis.

\section{NSAIDs use and CNS tumors risk}

Thirty-three independent reports from twelve studies investigated the association between NSAIDs use and CNS tumors risk. Compared with no NSAIDs use, NSAIDs use was significantly associated with a lower risk of CNS tumors risk (RR:0.89; 95\% CI, 0.81-0.95; $P=0.001$ ) (Table 3). Furthermore, NSAIDs use was associated with significantly a lower risk of glioma
(RR:0.92; 95\% CI, 0.87-0.98; $P=0.012$ ) (Table 3), glioblastoma (RR:0.86; 95\% CI, 0.73-0.98; $P<0.001$ ) (Table 3 ) but not meningioma (RR:0.73; 95\% CI, 0.48$1.12 ; P=0.149$ ) (Table 3 ). That may be because there isn't enough data in meningioma and CNS tumors risk.

\section{Non-aspirin NSAIDs use and CNS tumors risk}

Twenty-two independent reports from ten studies investigated the association between non-aspirin NSAIDs use and CNS tumors risk. Non-aspirin NSAIDs use was significantly associated with a lower risk of CNS tumors risk (RR:0.86; 95\% CI, 0.78-0.94; $P=0.002$ ) (Table 4). Furthermore, non-aspirin NSAIDs use was associated with significantly a lower risk of glioma (RR:0.94; 95\% CI, 0.88-0.99; $P=0.042$ ) (Table 4), glioblastoma (RR:0.78; 95\% CI, 0.63-0.95; $P=0.014$ ) (Table 4) but not meningioma (RR:0.97; 95\% CI, 0.64-1.47; $P=0.880$ ) (Table 4).

\section{Aspirin use and CNS tumors risk}

Eleven independent reports from seven studies investigated the association between aspirin use and CNS tumors risk. Compared with no aspirin use, aspirin use was significantly associated with a lower risk of CNS tumors risk (RR:0.88; 95\% CI, 0.79-0.95; $P=0.006$ )(Table 5). Furthermore, aspirin use was associated with significantly a lower risk of glioma(RR:0.86; 95\% CI, 0.76-0.95; $P<0.001$ ) (Table 5) but not meningioma (RR:0.85; 95\% CI, 0.65-1.12; $P=0.253$ ) (Table 5) and glioblastoma (RR:0.91; 95\% CI, 0.55-1.50; $P=0.701$ ) (Table 5)

\section{Dose-response between NSAIDs use and CNS tumors risk}

Use restricted cubic spline function, the test for a nonlinear dose-response relationship was significant (likelihood ratio test, $P<0.001$ ), suggesting curvature in the relationship between NSAIDs use and CNS tumors risk. Increasing cumulative 100 defined daily dose of NSAIDs use was associated with a $5 \%$ decrement of CNS tumors risk, the summary relative risk of CNS tumors risk for an per cumulative 100 defined daily dose of NSAIDs use was 0.95 (95\% CI: 0.92-0.98, $P=0.003$ ) (Figure 2). Furthermore, increasing NSAIDs use (per 3 prescriptions increment) was associated with a $7 \%$ decrement of CNS tumors risk, the summary relative risk of CNS tumors risk for an per 3 prescriptions increment of NSAIDs use was 0.93 (95\% CI: $0.88-0.97, P<0.001$ ) (Figure 3). Increasing non-aspirin NSAIDs use (per 3 prescriptions increment) was associated with a $7 \%$ decrement of CNS tumors risk, the summary relative risk of CNS tumors risk for an per 3 prescriptions increment of non-aspirin NSAIDs use was 0.93 (95\% CI: $0.89-0.97, P<0.001)$ (Figure 4). Increasing aspirin use (per 3 prescriptions increment) was 
associated with a $10 \%$ decrement of CNS tumors risk, the summary relative risk of CNS tumors risk for an per 3 prescriptions increment of aspirin use was 0.90 (95\% CI: $0.85-0.95, P<0.001$ ) (Figure 5). Additionally, increasing per 2 year of duration of NSAIDs use was associated with a $6 \%$ decrement of CNS tumors risk, the summary relative risk of CNS tumors risk for an per 2 year of duration of NSAIDs use was 0.94 (95\% CI: $0.92-0.98, P=0.001$ ) (Figure 6), increasing per 2 year of duration of non-aspirin NSAIDs use was associated with a $8 \%$ decrement of CNS tumors risk, the summary relative risk of CNS tumors risk for an per 2 year of duration of non-aspirin NSAIDs use was 0.92 (95\% CI: 0.87-0.97, $P=0.001$ ) (Figure 7), increasing per 2 year of duration of aspirin use was associated with a $6 \%$ decrement of CNS tumors risk, the summary relative risk of CNS tumors risk for an per 2 year of duration of aspirin use was 0.94 (95\% CI: 0.88-0.98, $P=0.005)$ (Figure 8).

\section{Subgroup analyses}

Subgroup analysis was performed to check the stability of the primary outcome. Subgroup meta-analyses in study design, study quality, number of participants and number of cases showed consistent findings (Tables 3-5).

\section{Sensitivity analysis}

Sensitivity analysis was conducted to assess the stability of the results. The results show the association between NSAIDs use and CNS tumors risk were stable (Supplementary Figures 1-3).

\section{Publication bias}

Publication bias of NSAIDs use was evaluated with both Begg's and Egger's tests. Results from Egger's tests indicated no evidence of publication bias among these studies (Supplementary Table 1). A funnel plot for publication bias assessment is illustrated in Supplementary Figures 4-6.

\section{DISCUSSION}

In the current meta-analysis was based on 12 casecontrol or cohort study, with 667085 participants with 19394 incident cases. Thus, this meta analysis provides the most up-to-date epidemiological evidence supporting NSAIDs use is helpful for CNS tumors. A dose-response analysis revealed that increasing cumulative 100 defined daily dose of NSAIDs use was associated with a $5 \%$ decrement

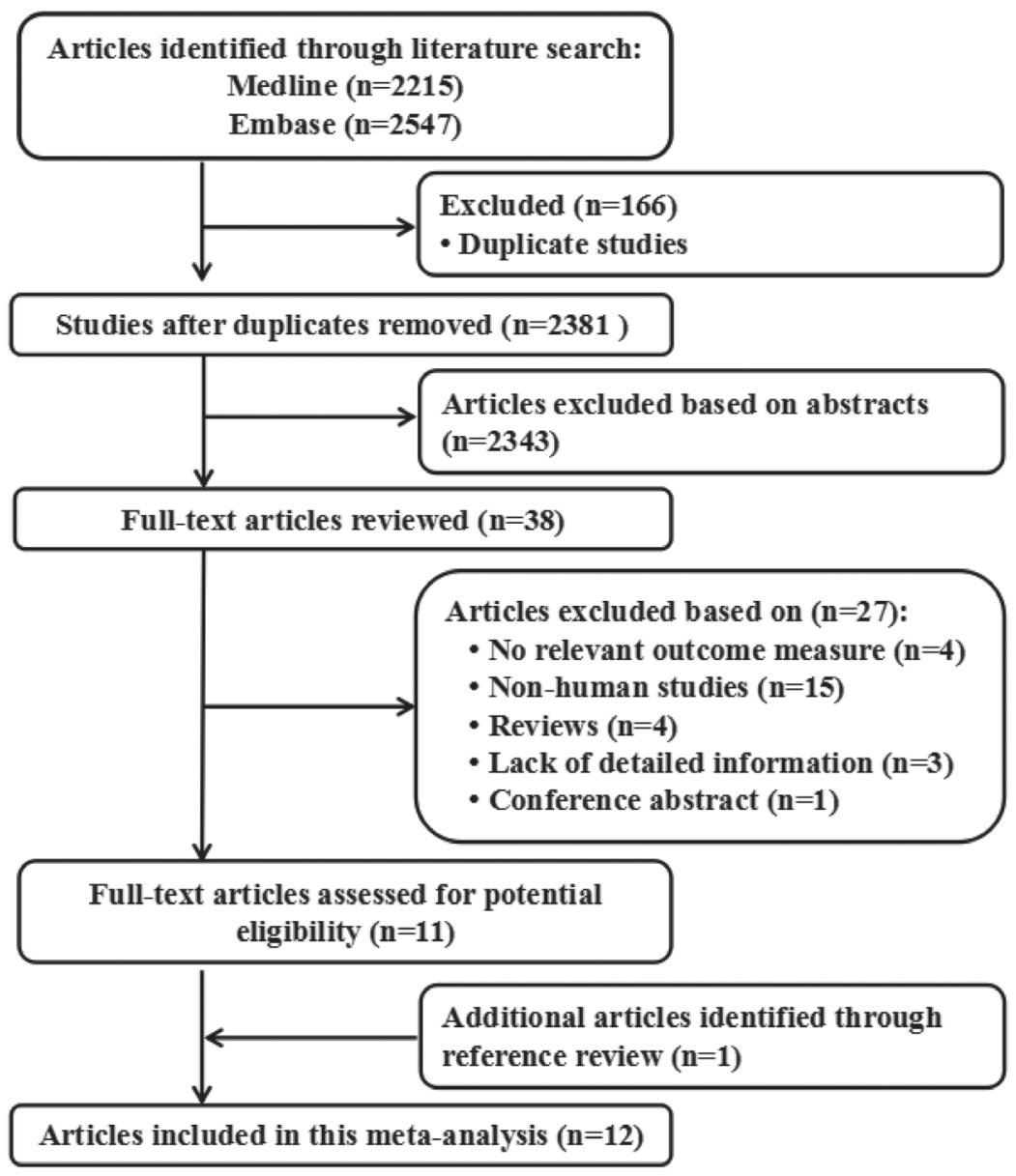

Figure 1: Flow diagram of the study selection process. 
Table 1: Characteristics of participants in included studies of nonsteroidal anti-inflammatory drugs using in relation to risk of central nervous system tumor

\begin{tabular}{|c|c|c|c|c|c|c|c|}
\hline Author(year) & Study design & Country & $\begin{array}{c}\text { Sex of } \\
\text { population }\end{array}$ & $\begin{array}{l}\text { Age at } \\
\text { baseline } \\
\text { (years) }\end{array}$ & $\begin{array}{c}\text { No of } \\
\text { participants }\end{array}$ & Endpoints (cases) & Quality score \\
\hline Bannon et al. (2013) & Case-control & $\begin{array}{l}\text { United } \\
\text { Kingdom }\end{array}$ & Mix & 58.0 & 47730 & $\begin{array}{c}\text { Brain tumours (5052) } \\
\text { Gliomas }(2313) \\
\text { Meningiomas (861) }\end{array}$ & 7 \\
\hline Gaist et al. (2013) & Case-control & Denmark & Mix & $20-85$ & 21536 & Gliomas (2688) & 7 \\
\hline Sivak-Sears et al. (2004) & Case-control & USA & Mix & $51-71.5$ & 637 & Glioblastoma (236) & 7 \\
\hline Scheurer et al. (2008) & Case-control & USA & Mix & 50 & 925 & Gliomas (325) & 6 \\
\hline Scheurer et al. (2011) & Case-control & USA & Mix & 53.5 & 2873 & Gliomas (1339) & 7 \\
\hline Ferris et al. (2012) & Case-control & USA & Mix & 57.4 & 917 & Gliomas (517) & 6 \\
\hline Seliger et al. (2015) & Case-control & $\begin{array}{l}\text { United } \\
\text { Kingdom }\end{array}$ & Mix & 55.5 & 22055 & Gliomas (2005) & 7 \\
\hline Seliger et al. (2016) & Case-control & $\begin{array}{l}\text { United } \\
\text { Kingdom }\end{array}$ & Mix & 55.3 & 27159 & Gliomas (2469) & 7 \\
\hline Friis et al. (2003) & Cohort & Denmark & Mix & 70.0 & 29470 & Brain tumours (193) & 7 \\
\hline Sørensen et al. (2003) & Cohort & USA & Mix & 47.2 & 172057 & Brain tumours (170) & 8 \\
\hline Daugherty et al. (2011) & Cohort & USA & Mix & 63.4 & 302767 & $\begin{array}{c}\text { Gliomas (674) } \\
\text { Glioblastoma (521) }\end{array}$ & 7 \\
\hline Cook et al. (2005) & $\begin{array}{l}\text { Randomized } \\
\text { clinical trial }\end{array}$ & USA & Female & 54.6 & 39876 & Brain tumours (31) & 6 \\
\hline
\end{tabular}

of CNS tumors risk, increasing NSAIDs or non-aspirin NSAIDs or aspirin use (per 3 prescriptions increment) was associated with a 7\%,7\%,10\% decrement of CNS tumors risk, increasing per 2 year of duration of NSAIDs or nonaspirin NSAIDs or aspirin use was associated with a $6 \%$, $8 \%, 6 \%$ decrement of CNS tumors risk.

Previous meta-analysis reported the association between NSAIDs use and brain tumour risk, and found NSAIDs use did not appear to be associated with brain tumour risk [24]. Though, the result is quite different with ours, it still exist some problems. On the one hand, previous meta-analysis included just ten reports from ten studies, our meta-analysis included thirty-three independent reports from twelve studies, the quantity of reports involving in their meta-analysis was smaller, which weak the persuasive power of their research, and our results become more convincing. On the other hand, previous meta-analysis did not include all NSAIDs in the study, this may be affect the result and all NSAIDs acted as a independent report in our meta-analysis.

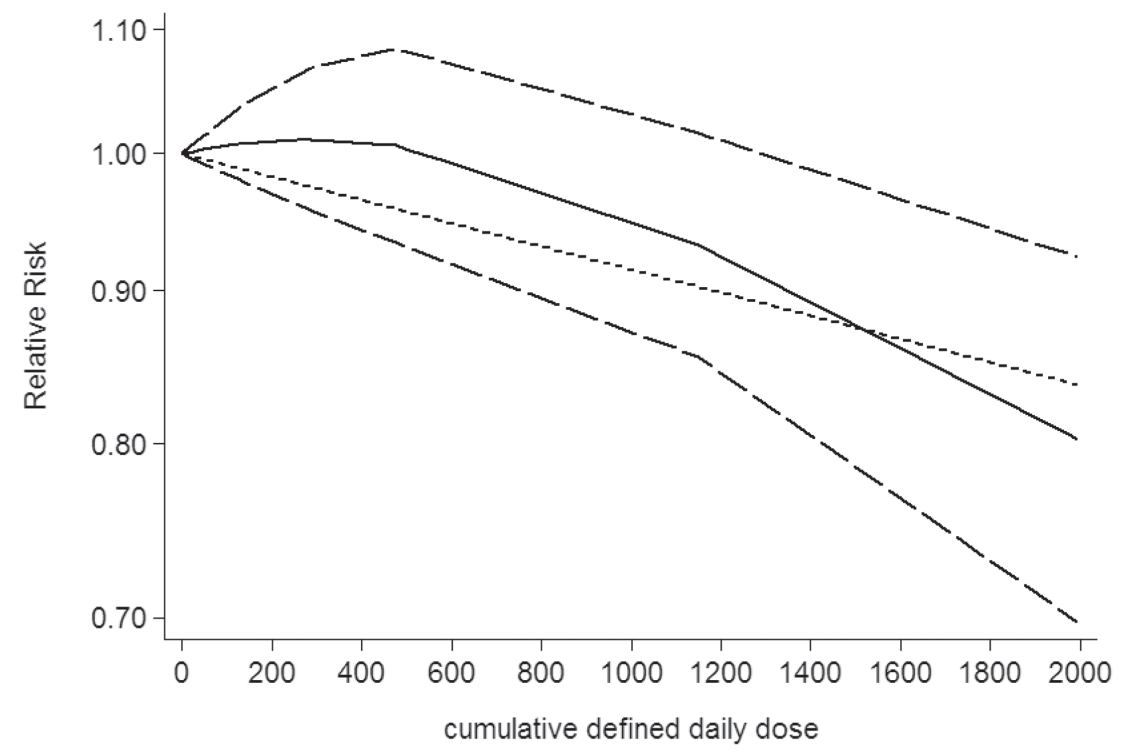

Figure 2: Dose-response relationship between cumulative daily dose of NSAIDs use in relation to risk of central nervous system tumor. 
Several plausible pathways may reasonable for the relationship between NSAIDs use and CNS tumors risk. Firstly, NSAIDs have been found to inhibit or kill glioma cells, and the nonsteroidal anti-inflammatory drug can suppresses the growth and induces apoptosis of human glioblastoma cells via the NF-kappaB pathway [25-27]. Secondly, refractoriness of glioblastoma multiforme (GBM) largely depends on its radioresistance, and celecoxib enhances radiosensitivity of hypoxic glioblastoma cells through endoplasmic reticulum stress [28-31]. Third, NSAIDs use can significantly enhance glioblastoma radiosensitivity, reduced clonogenic survival, and prolonged survival of glioblastoma-implanted mice by inhibition of tumor angiogenesis with extensive tumor necrosis and reduce angiogenesis [32-34]. Fourth, NSAIDs use is sufficient to render unmodified tumor cells

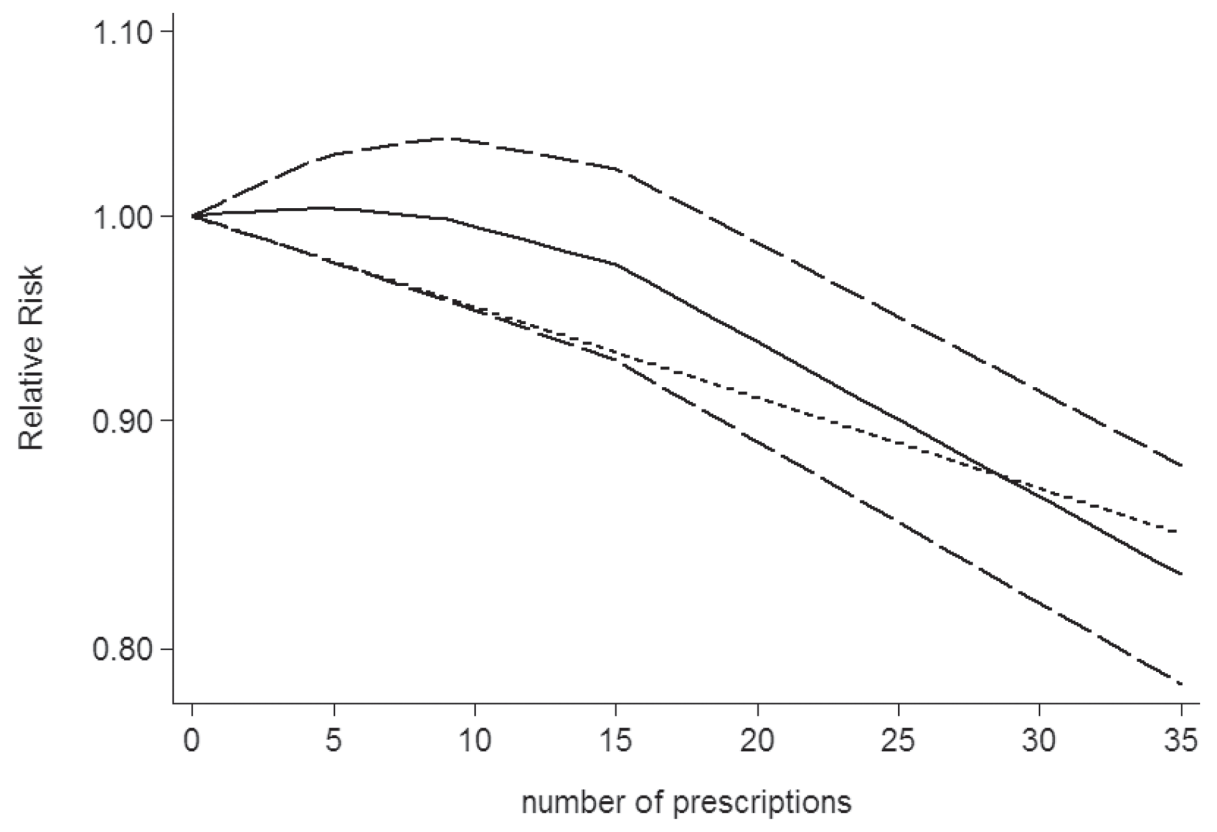

Figure 3: Dose-response relationship between number of prescriptions of NSAIDs use in relation to risk of central nervous system tumor.

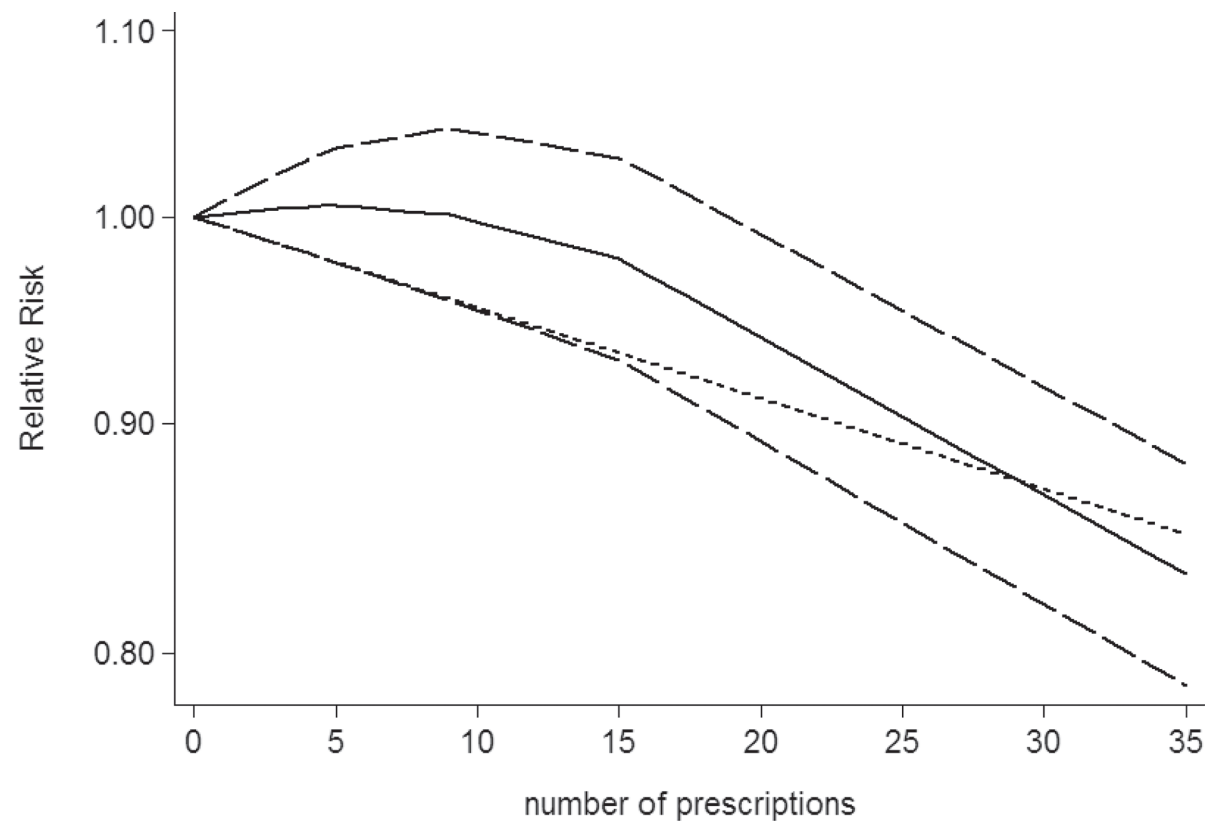

Figure 4: Dose-response relationship between number of prescriptions of non-aspirin NSAIDs use in relation to risk of central nervous system tumor. 
Table 2: Outcomes and covariates of included studies of nonsteroidal anti-inflammatory drugs using in relation to risk of central nervous system tumor

\begin{tabular}{|c|c|c|c|c|}
\hline Author (year) & Endpoints & Data source & Category and relative risk $(95 \% \mathrm{CI})$ & Covariates in fully adjusted model \\
\hline Bannon et al. (2013) & $\begin{array}{l}\text { Brain tumours }(5052) \\
\text { Gliomas }(2313) \\
\text { Meningiomas }(861)\end{array}$ & Population-based & $\begin{array}{l}\text { Non-aspirin NSAIDs } \\
\text { Gliomas } \\
0 \text { DDDs, } 1.0 \text { (reference); }>0-<28,1.00(0.85,1.16) \text {; } \\
>28-<65,0.99(0.85,1.16) ;>65-<212,1.21(1.04 \text {, } \\
\text { 1.40); }>212,0.96(0.82,1.1 .13) \\
\text { Meningiomas } \\
0 \text { DDDs, } 1.0 \text { (reference); }>0-<28,1.02(0.79,1.31) \text {; } \\
>28-<65,1.40(1.10,1.77) ;>65-<212,1.32(1.04, \\
1.67) ;>212,1.35(1.06,1.71) \\
\text { Aspirin } \\
\text { Gliomas } \\
0 \text { DDDs, } 1.0(\text { reference }) ;>0-<224,1.08(0.85 \\
1.38) ;>224-<728,1.09(0.86,1.40) ;>728-<1572 \text {, } \\
1.01(0.78,1.31) ;>1572,0.85(0.65,1.12) \\
\text { Meningiomas } \\
0 \text { DDDs, } 1.0(\text { reference }) ;>0-<224,1.39(0.98,1.97) \text {; } \\
>224-<728,1.29(0.88,1.90) ;>728-<1572,0.88 \\
(0.58,1.32) ;>1572,0.97(0.64,1.47)\end{array}$ & $\begin{array}{l}\text { Adjusted for age,sex, history of } \\
\text { osteoarthritis/arthralgia;history of } \\
\text { rheumatoid arthritis, history of allergy, } \\
\text { history of hormone replacement } \\
\text { therapy use. }\end{array}$ \\
\hline Gaist et al. (2013) & Gliomas (2688) & Self-administered & $\begin{array}{l}\text { Recent use, years } \\
\text { Non-aspirin NSAIDs } \\
\text { Never use, } 1.0 \text { (reference); }>0-<2,1.06(0.95,1.17) \text {; } \\
>2-<4,0.97(0.60,1.57) ;>5,1.11(0.57,2.17) \\
\text { Aspirin } \\
\text { Never use, } 1.0 \text { (reference); }>0-<2,0.96(0.79,1.16) \text {; } \\
>2-<4,0.80(0.60,1.06) ;>5,0.80(0.53,1.21) \\
\text { Past use, years } \\
\text { Non-aspirin NSAIDs } \\
\text { Never use, } 1.0 \text { (reference); }>0-<2,1.05(0.95,1.17) \text {; } \\
>2,0.91(0.29,2.83) \\
\text { Aspirin } \\
\text { Never use, } 1.0 \text { (reference); }>0-<2,0.84(0.61,1.15) \\
>2,0.47(0.14,1.15)\end{array}$ & $\begin{array}{l}\text { Adjusted for education, diabetes, } \\
\text { stroke, allergy, asthma, use of statins, } \\
\text { antihistamines, and anti-asthma } \\
\text { medication }\end{array}$ \\
\hline $\begin{array}{l}\text { Sivak-Sears et al. } \\
(2004)\end{array}$ & Glioblastoma (236) & Population-based & $\begin{array}{l}\text { Recent use, years } \\
\text { Ibuprofen } \\
\text { Never use, } 1.0 \text { (reference); }>0-<5,0.32(0.10,0.70) \\
>5,1.04(0.60,1.80) \\
\text { Naproxen } \\
\text { Never use, } 1.0 \text { (reference); }>0-<3,0.75(0.30,1.70) \\
>3,0.50(0.20,1.20) \\
\text { Acetaminophen } \\
\text { Never use, } 1.0 \text { (reference); }>0-<10,0.72(0.30,1.50) \text {; } \\
>10,1.08(0.60,2.00) \\
\text { Aspirin } \\
\text { Never use, } 1.0 \text { (reference); }>0-<10,0.71(0.40,1.20) \\
>10,0.66(0.40,1.10)\end{array}$ & $\begin{array}{l}\text { Adjustment for gender, ethnicity, } \\
\text { income, and education }\end{array}$ \\
\hline $\begin{array}{l}\text { Scheurer et al. } \\
\text { (2011) }\end{array}$ & Gliomas (1339) & Population-based & $\begin{array}{l}\text { NSAIDs } \\
\text { Never use, } 1.0 \text { (reference); }>0-<10,0.55(0.35,0.88) \text {; } \\
>10,0.65(0.39,1.07)\end{array}$ & $\begin{array}{l}\text { Adjusted for age, race, sex, education, } \\
\text { study series, family history of brain } \\
\text { tumors, and history of chickenpox and } \\
\text { controlled for all other covariates in } \\
\text { the table. }\end{array}$ \\
\hline Ferris et al. (2012) & Gliomas (517) & Self-administered & $\begin{array}{l}\text { Recent use, years } \\
\text { Aspirin } \\
<6 \text { Months, } 1.0(\text { reference }) ;>7-<24,0.57(0.30,1.08) \\
>25-<60,0.64(0.38,1.06) ;>60,0.80(0.51,1.24) \\
\text { Ibuprofen } \\
<6 \text { Months, } 1.0(\text { reference }) ;>7-<24,1.49(0.40,5.54) \\
>25-<60,1.06(0.55,2.06) ;>60,1.08(0.64,1.84) \\
\text { Naproxen } \\
<6 \text { Months, } 1.0 \text { (reference); }>7-<24,3.40(0.68,17.34) ; \\
>25-<60,0.85(0.23,2.98) ;>60,0.37(0.13,1.11) \\
\text { All NSAIDs } \\
<6 \text { Months, } 1.0(\text { reference }) ;>7-<24,0.70(0.35,1.38) \\
>25-<60,0.75(0.46,1.23) ;>60-<120,0.73(0.49 \\
1.08) ;>120,0.62(0.38,1.00)\end{array}$ & $\begin{array}{l}\text { Adjusted for individual statins, } \\
\text { NSAIDs, age, race, gender and center }\end{array}$ \\
\hline Seliger et al. (2015) & Gliomas (2005) & Population-based & $\begin{array}{l}\text { Number of prescriptions } \\
\text { NSAIDs } \\
\text { Never use, } 1.0 \text { (reference); }>1-<9,0.98(0.89,1.08) \text {; } \\
>10,1.05(0.84,1.33) \\
\text { Aspirin } \\
\text { Never use, } 1.0 \text { (reference); }>1-<14,0.78(0.55,1.11) \text {; } \\
>15,1.22(0.76,1.94)\end{array}$ & $\begin{array}{l}\text { Adjusted for age, sex, general practice, } \\
\text { number of years of active history in } \\
\text { the database, and adjusted for BMI and } \\
\text { smoking }\end{array}$ \\
\hline
\end{tabular}




\begin{tabular}{|c|c|c|c|c|}
\hline Seliger et al. (2016) & Gliomas (2469) & Self-administered & $\begin{array}{l}\text { Number of prescriptions } \\
\text { Aspirin } \\
\text { Never use, } 1.0 \text { (reference); }>1-<9,0.83(0.60,1.15) \text {; } \\
>10-<29,0.80(0.43,1.50) ;>30,1.19(0.66,2.13) \\
\text { COX-2 inhibitors } \\
\text { Never use, } 1.0 \text { (reference); }>1-<9,1.02(0.92,1.13) ; \\
>10-<29,1.01(0.80,1.28) ;>30,1.16(0.76,1.55) \\
\text { Ibuprofen } \\
\text { Never use, } 1.0 \text { (reference); }>1-<9,0.95(0.86,1.05) ; \\
>10-<29,1.03(0.77,1.39) ;>30,0.94(0.60,1.48) \\
\text { Naproxen } \\
\text { Never use, } 1.0 \text { (reference); }>1-<9,0.91(0.79,1.05) ; \\
>10-<29,0.52(0.28,0.96) ;>30,1.45(0.83,2.52)\end{array}$ & $\begin{array}{l}\text { Adjusted for age, sex, general practice, } \\
\text { and number of years of active history } \\
\text { in the database, body mass index, } \\
\text { smoking, diabetes, congestive heart } \\
\text { failure, and all other medications in } \\
\text { this table }\end{array}$ \\
\hline $\begin{array}{l}\text { Daugherty et al. } \\
\text { (2011) }\end{array}$ & $\begin{array}{l}\text { Gliomas (674) } \\
\text { Glioblastoma (521) }\end{array}$ & Population-based & $\begin{array}{l}\text { Number of prescriptions } \\
\text { Glioma } \\
\text { Aspirin } \\
\text { Never use, } 1.0 \text { (reference); }>0-<2,1.21(0.91,1.61) ; \\
>2-<6,1.07(0.70,1.62) ;>7,1.21(0.88,1.65) \\
\text { Non Aspirin NSAID } \\
\text { Never use, } 1.0 \text { (reference); }>0-<2,1.06(0.84,1.33) ; \\
>2-<6,0.87(0.53,1.44) ;>7,0.92(0.62,1.36) \\
\text { Glioblastoma } \\
\text { Aspirin } \\
\text { Never use, } 1.0 \text { (reference); }>0-<2,1.30(0.94,1.80) ; \\
>2-<6,1.06(0.65,1.72) ;>7,1.21(0.84,1.75) \\
\text { Non Aspirin NSAID } \\
\text { Never use, } 1.0 \text { (reference); }>0-<2,1.03(0.79,1.34) ; \\
>2-<6,0.58(0.30,1.15) ;>7,0.96(0.62,1.49)\end{array}$ & $\begin{array}{l}\text { Adjusting for sex, race, and history of } \\
\text { heart disease using age as time metric }\end{array}$ \\
\hline
\end{tabular}

Abbreviations: DDD: defined daily dose.

immunogenic in immunotherapy of experimental brain tumors, and stimulate anti-tumour immune reactions in vitro and in established animal models [35-37]. However, the potential mechanisms of NSAIDs use and tumor growth still remain unclear and controversial.

To our knowledge, this is the first comprehensive study to identify and quantify the potential dose-response association between NSAIDs use and CNS tumors risk in both men and women. Although, we performed this meta-analysis very carefully, some limitations must be considered in the current meta-analysis. Firstly, despite we searched all studies describing the association between NSAIDs use and CNS tumors risk, there are only 12 studies about NSAIDs use and CNS tumors risk, the number of eligible studies was still limited. On the other hand, 12 studies from only three countries, different ethnic population are warranted to validate the association between NSAIDs use and CNS tumors risk. Thirdly, we only select literature that written by English, which may have resulted in a language or cultural bias,

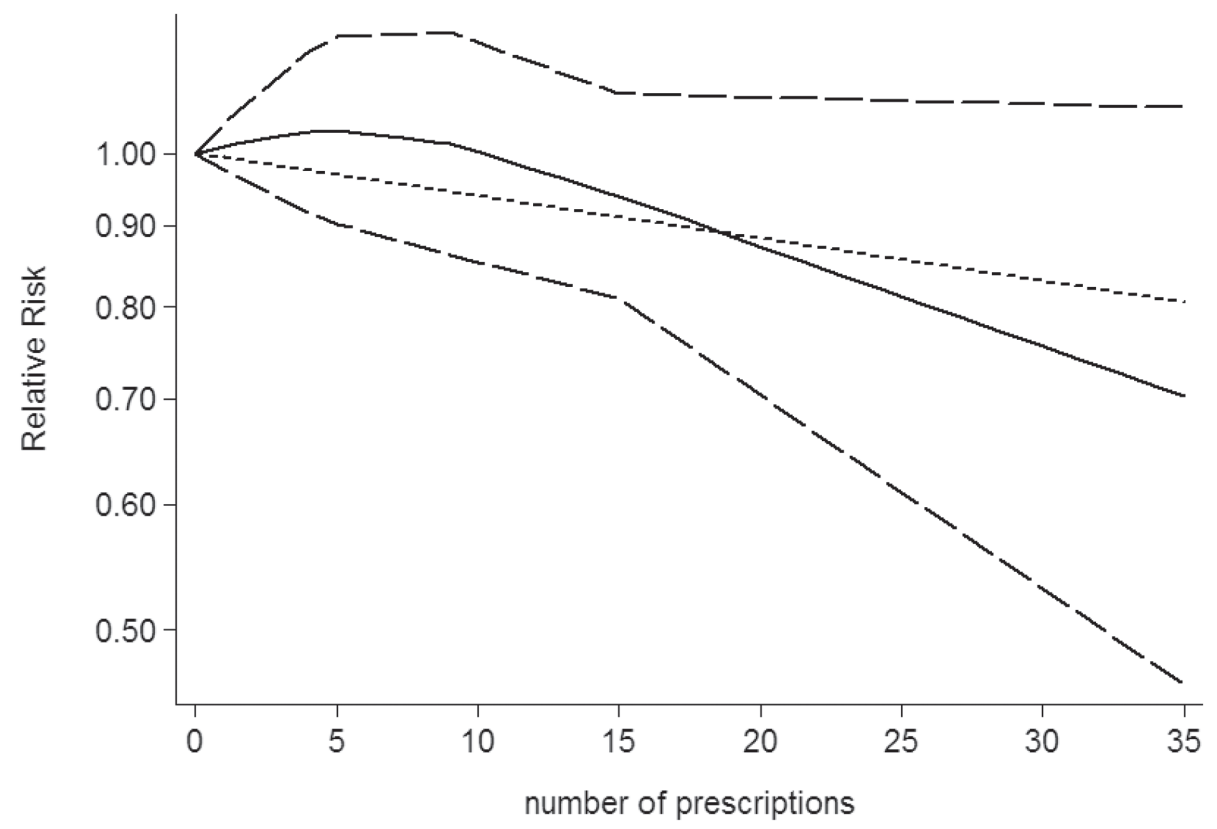

Figure 5: Dose-response relationship between number of prescriptions of aspirin use in relation to risk of central nervous system tumor. 
other languages should be chosen in the further. Fourth, in the subgroup analysis in CNS tumors type, there has no insufficient statistical power to check a dose-response in different CNS tumors type, large data in different CNS tumors type is warranted to validate this association.

In conclusion, our findings underscore the notion that NSAIDs use was significantly associated with CNS tumors risk decrement. In the future, large-scale casecontrol and population based association studies must be performed in the future to validate the risk identified in the current meta-analysis.

\section{MATERIALS AND METHODS}

Our meta-analysis was conducted according to the Meta-analysis Of Observational Studies in Epidemiology (MOOSE) checklist [38].

\section{Search strategy}

We included eligible studies investigating the relationship of NSAIDs use and CNS tumors risk. To develop a flexible, non-linear, r meta-regression model,

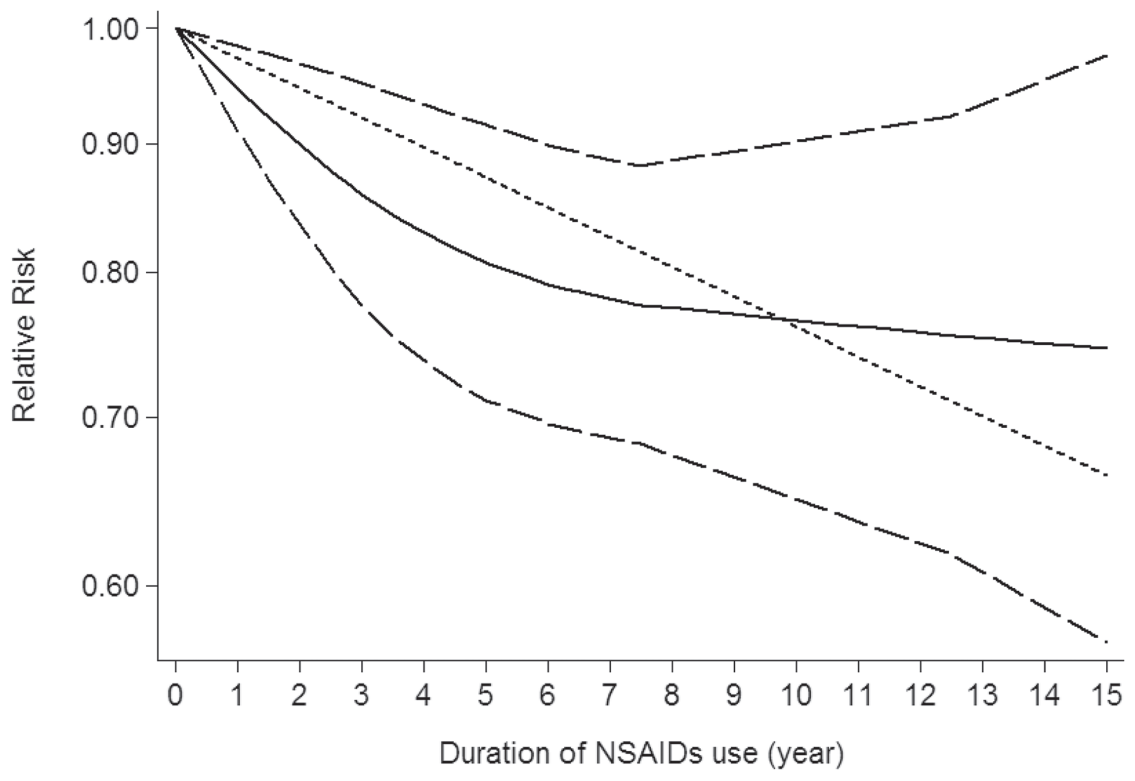

Figure 6: Dose-response relationship between duration of NSAIDs use in relation to risk of central nervous system tumor.

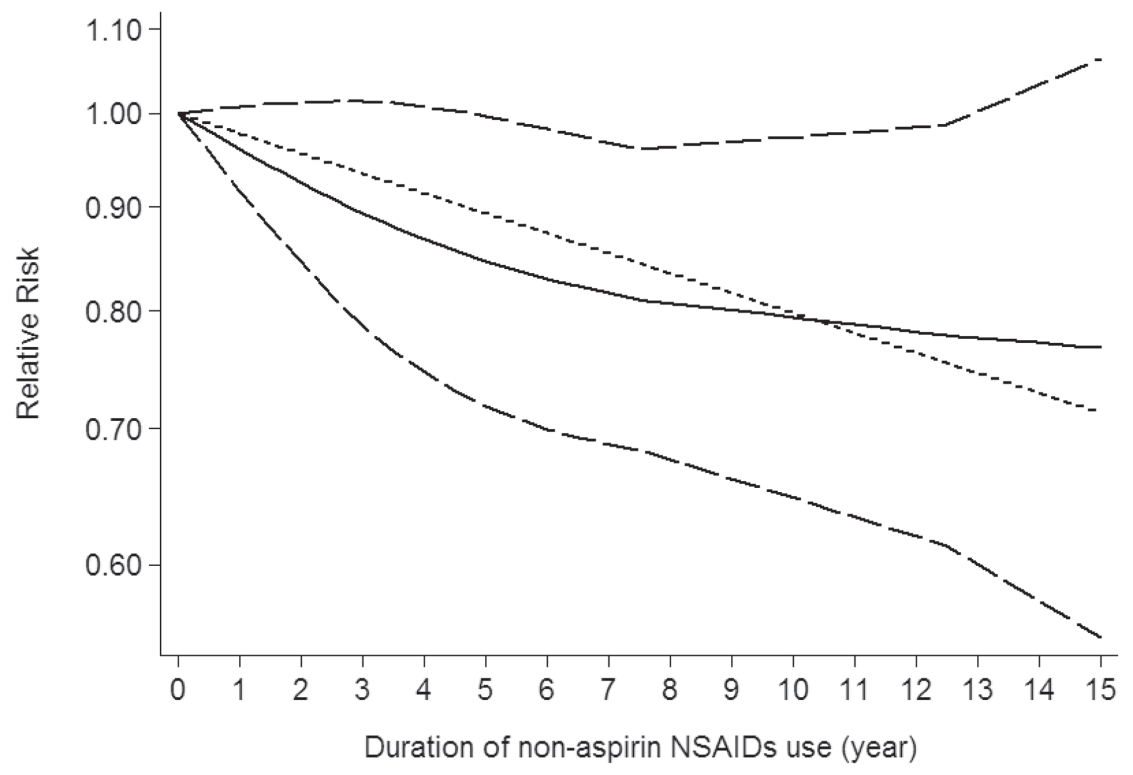

Figure 7: Dose-response relationship between duration of non-aspirin NSAIDs use in relation to risk of central nervous system tumor. 
Table 3: Stratified analyses of relative risk of central nervous system tumor risk

\begin{tabular}{|c|c|c|c|c|c|}
\hline \multirow[t]{2}{*}{ Studies groups } & \multirow{2}{*}{ No of reports } & \multirow{2}{*}{ Relative risk $(95 \% \mathrm{CI})$} & \multicolumn{2}{|c|}{ Heterogeneity } & \multirow{2}{*}{$P$ for test } \\
\hline & & & $P$ value & $I^{2}(\%)$ & \\
\hline Total & 33 & $0.89(0.81-0.95)$ & 0.000 & $55.8 \%$ & 0.001 \\
\hline \multicolumn{6}{|c|}{ Subgroup analyses for nonsteroidal anti-inflammatory drugs using } \\
\hline \multicolumn{6}{|l|}{ Type of drugs use } \\
\hline Non-aspirin NSAIDs using & 22 & $0.86(0.78-0.92)$ & 0.001 & $54.9 \%$ & 0.002 \\
\hline Aspirin using & 11 & $0.88(0.79-0.95)$ & 0.014 & $54.8 \%$ & 0.006 \\
\hline \multicolumn{6}{|l|}{ Tumour subtype } \\
\hline Glioma & 18 & $0.92(0.87-0.98)$ & 0.000 & $55.3 \%$ & 0.012 \\
\hline Meningioma & 2 & $0.73(0.48-1.12)$ & 0.135 & $55.3 \%$ & 0.149 \\
\hline Glioblastoma & 7 & $0.86(0.73-0.98)$ & 0.177 & $39.1 \%$ & $<0.001$ \\
\hline \multicolumn{6}{|l|}{ Study design } \\
\hline Case-control & 27 & $0.89(0.83-0.96)$ & 0.000 & $60.5 \%$ & 0.001 \\
\hline Cohort & 6 & $0.93(0.83-0.99)$ & 0.256 & $23.7 \%$ & 0.043 \\
\hline \multicolumn{6}{|l|}{ No of participants } \\
\hline$\geq 10000$ & 23 & $0.94(0.86-0.99)$ & 0.000 & $57.6 \%$ & 0.038 \\
\hline$<10000$ & 10 & $0.72(0.62-0.83)$ & 0.705 & $0.0 \%$ & $<0.001$ \\
\hline \multicolumn{6}{|l|}{ No of cases } \\
\hline$\geq 1000$ & 21 & $0.94(0.87-0.99)$ & 0.000 & $59.1 \%$ & 0.041 \\
\hline$<1000$ & 12 & $0.80(0.68-0.90)$ & 0.051 & $43.8 \%$ & $<0.001$ \\
\hline \multicolumn{6}{|l|}{ Study quality } \\
\hline Score $\geq 7$ & 30 & $0.83(0.73-0.93)$ & 0.000 & $65.4 \%$ & $<0.001$ \\
\hline Score $<7$ & 3 & $0.95(0.86-1.05)$ & 0.313 & $0.0 \%$ & 0.413 \\
\hline
\end{tabular}

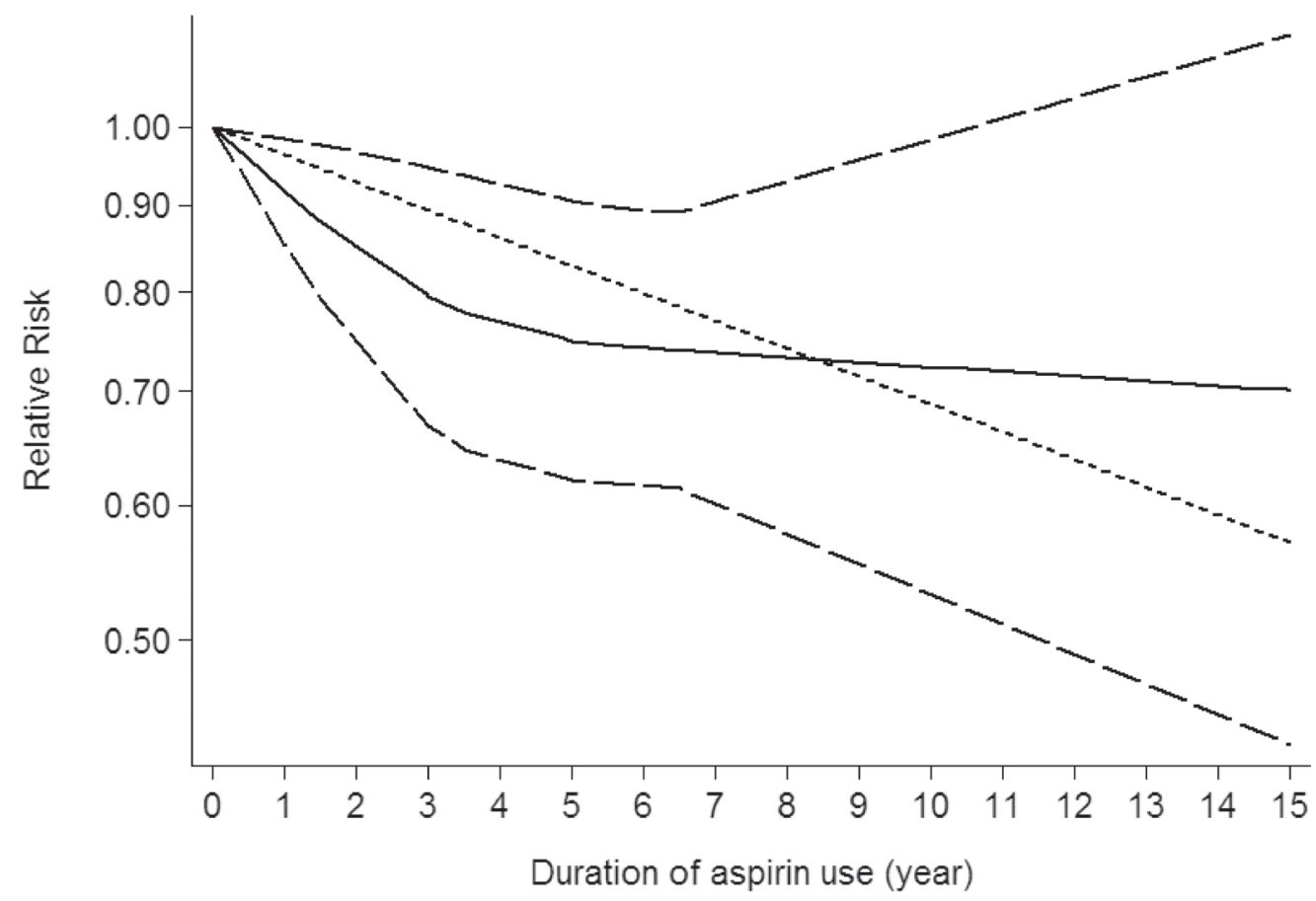

Figure 8: Dose-response relationship between duration of aspirin use in relation to risk of central nervous system tumor. 
Table 4: Associations between non-aspirin NSAIDs using and central nervous system tumor risk in subgroup meta-analyses

\begin{tabular}{|c|c|c|c|c|c|}
\hline \multirow[t]{2}{*}{ Studies groups } & \multirow[t]{2}{*}{ No of reports } & \multirow[t]{2}{*}{ Relative risk $(95 \% \mathrm{CI})$} & \multicolumn{2}{|c|}{ Heterogeneity } & \multirow[t]{2}{*}{$P$ for test } \\
\hline & & & $P$ value & $I^{2}(\%)$ & \\
\hline Total & 22 & $0.86(0.78-0.92)$ & 0.001 & $54.9 \%$ & 0.002 \\
\hline \multicolumn{6}{|l|}{ Tumour subtype } \\
\hline Glioma & 16 & $0.94(0.88-0.99)$ & 0.003 & $57.0 \%$ & 0.042 \\
\hline Meningioma & 1 & $0.97(0.64-1.47)$ & & & 0.880 \\
\hline Glioblastoma & 5 & $0.78(0.63-0.95)$ & 0.883 & $0.0 \%$ & 0.014 \\
\hline \multicolumn{6}{|l|}{ Study design } \\
\hline Case-control & 19 & $0.88(0.78-0.95)$ & 0.000 & $60.3 \%$ & $<0.001$ \\
\hline Cohort & 3 & $0.93(0.85-0.98)$ & 0.686 & $0.0 \%$ & 0.013 \\
\hline \multicolumn{6}{|c|}{ No of participants } \\
\hline$\geq 10000$ & 17 & $0.87(0.78-0.91)$ & 0.000 & $66.0 \%$ & 0.003 \\
\hline$<10000$ & 5 & $0.91(0.85-0.97)$ & 0.155 & $46.3 \%$ & $<0.001$ \\
\hline \multicolumn{6}{|l|}{ No of cases } \\
\hline$\geq 1000$ & 11 & $0.83(0.73-0.94)$ & 0.162 & $24.2 \%$ & 0.005 \\
\hline$<1000$ & 11 & $0.90(0.81-0.98)$ & 0.001 & $65.8 \%$ & 0.013 \\
\hline \multicolumn{6}{|l|}{ Study quality } \\
\hline Score $\geq 7$ & 20 & $0.88(0.78-0.98)$ & 0.002 & $54.6 \%$ & 0.007 \\
\hline Score $<7$ & 2 & $0.74(0.67-0.82)$ & 0.448 & $0.0 \%$ & $<0.001$ \\
\hline
\end{tabular}

we required that an eligible study should have categorized into 3 or more levels.

Eligible studies were systematically searched of PubMed and Embase update to July 2017 for case control or cohort studies examining the relationship between NSAIDs use and CNS tumors risk, with keywords including "brain cancer" [MeSH] OR "glioma"[MeSH] OR "glioblastoma" [MeSH] OR "meningioma" [MeSH] AND "aspirin" [MeSH] OR "NSAIDs" [MeSH] OR "ibuprofen" [MeSH] OR "naproxen" [MeSH] OR "indomethacin" $[\mathrm{MeSH}]$ OR "meloxicam" [MeSH] OR "nimesulide" [MeSH] OR "celecoxib" [MeSH] OR "rofecoxib" [MeSH] OR "acetaminophen" [MeSH] OR "diclofenac" [MeSH]. We refer to the relevant original essays and commentary articles to determine further relevant research.

\section{Study selection}

Two independent researchers investigate information the correlation between NSAIDs use and CNS tumors risk: outcome was CNS tumors; the relative risks at least three quantitative categories of NSAIDs use and CNS tumors risk. Moreover, we precluded non-human studies, reviews, editorials and published letters.

\section{Data extraction}

Use standardized data collection tables to extract data. We extracted the following information: first author; publication year; age; country; sex; cases and participants; the categories of NSAIDs use; relative risk(RR) or odds ratio (OR). We collect the risk estimates with multivariableadjusted. According to the Newcastle-Ottawa scale [39], quality assessment was performed for non-randomized studies.

\section{Statistical analysis}

We pooled relative risk estimates to measure the association between NSAIDs use and CNS tumors risk; the hazard ratio were considered equivalent to the relative risk [40]. Results in different subgroups of NSAIDs use and CNS tumors risk were treated as two separate reports.

Due to different definitions cut-off points in the included studies for categories, we performed a relative risk estimates by increasing cumulative 100 defined daily dose of NSAIDs use or per 3 prescriptions of NSAIDs use or per 2 year of duration of NSAIDs use the method recommended by Greenland, Longnecker and Orsini and colleagues [41]. In addition, use restricted cubic splines to evaluate the non-linear association between NSAIDs use and CNS tumors risk, with three knots at the 10th, 50th, and 90th percentiles of the distribution. A flexible meta-regression based on restricted cubic spline (RCS) function was used to fit the potential non-linear trend, and generalized least-square method was used to estimate the parameters. This procedure treats NSAIDs use (continuous data) as an independent variable and $\log R \mathrm{R}$ of diseases as a dependent variable, with both tails of the curve restricted 
Table 5: Associations between aspirin using and central nervous system tumor risk in subgroup meta-analyses

\begin{tabular}{|c|c|c|c|c|c|}
\hline \multirow[t]{2}{*}{ Studies groups } & \multirow[t]{2}{*}{ No of reports } & \multirow[t]{2}{*}{ Relative risk $(95 \% \mathrm{CI})$} & \multicolumn{2}{|c|}{ Heterogeneity } & \multirow[t]{2}{*}{$P$ for tes } \\
\hline & & & $P$ value & $I^{2}(\%)$ & \\
\hline Total & 11 & $0.88(0.79-0.95)$ & 0.014 & $54.8 \%$ & 0.006 \\
\hline \multicolumn{6}{|l|}{ Tumour subtype } \\
\hline Glioma & 8 & $0.86(0.76-0.95)$ & 0.013 & $43.8 \%$ & $<0.001$ \\
\hline Meningioma & 1 & $0.85(0.65-1.12)$ & & & 0.253 \\
\hline Glioblastoma & 2 & $0.91(0.55-1.50)$ & 0.038 & $76.7 \%$ & 0.701 \\
\hline \multicolumn{6}{|l|}{ Study design } \\
\hline Case-control & 8 & $0.83(0.72-0.96)$ & 0.032 & $54.4 \%$ & 0.001 \\
\hline Cohort & 3 & $0.92(0.82-0.96)$ & 0.055 & $65.5 \%$ & 0.025 \\
\hline \multicolumn{6}{|c|}{ No of participants } \\
\hline$\geq 10000$ & 10 & $0.85(0.75-0.96)$ & 0.021 & $54.1 \%$ & 0.003 \\
\hline$<10000$ & 1 & $1.08(0.64-1.34)$ & & & 0.651 \\
\hline \multicolumn{6}{|l|}{ No of cases } \\
\hline$\geq 1000$ & 10 & $0.85(0.75-0.96)$ & 0.021 & $54.1 \%$ & 0.003 \\
\hline$<1000$ & 1 & $1.08(0.64-1.34)$ & & & 0.651 \\
\hline \multicolumn{6}{|l|}{ Study quality } \\
\hline Score $\geq 7$ & 10 & $0.85(0.75-0.96)$ & 0.021 & $54.1 \%$ & 0.003 \\
\hline Score $<7$ & 1 & $1.08(0.64-1.34)$ & & & 0.651 \\
\hline
\end{tabular}

to linear. A $P$ value is calculated for linear or non-linear by testing the null hypothesis that the coefficient of the second spline is equal to zero [42].

We use STATA software 12.0 (STATA Corp, College Station, TX, USA) to evaluate the relationships between NSAIDs use and CNS tumors risk. Heterogeneity among studies used $\mathrm{Q}$ test and $\mathrm{I}^{2}$ statistic to assess. If $P_{\mathrm{Q}}<0.10$ or $\mathrm{I}^{2}>50 \%$, random-effect model was chosen, otherwise, fixed-effect mode was applied. Begg's and Egger's tests were to assess the publication bias of each study. $P<0.05$ was considered signifcant for all tests.

\section{CONFLICTS OF INTEREST}

Authors have disclosed no conflicts of interest.

\section{FUNDING}

This study received no specific external funding.

\section{REFERENCES}

1. McKinney PA. Brain tumours: incidence, survival, and aetiology. J Neurol Neurosurg Psychiatry. 2004; 75:ii12-7.

2. Ohgaki H. Epidemiology of brain tumors. Methods Mol Biol. 2009; 472:323-42.

3. Stupp R, Hegi ME, Mason WP, van den Bent MJ, Taphoorn MJ, Janzer RC, Ludwin SK, Allgeier A, Fisher B, Belanger
K, Hau P, Brandes AA, Gijtenbeek J, et al. Effects of radiotherapy with concomitant and adjuvant temozolomide versus radiotherapy alone on survival in glioblastoma in a randomised phase III study: 5-year analysis of the EORTCNCIC trial. Lancet Oncol. 2009; 10:459-66.

4. Inskip PD, Linet MS, Heineman EF. Etiology of brain tumors in adults. Epidemiol Rev. 1995; 17:382-414.

5. Fujita M, Kohanbash G, Fellows-Mayle W, Hamilton RL, Komohara Y, Decker SA, Ohlfest JR, Okada H. COX-2 blockade suppresses gliomagenesis by inhibiting myeloidderived suppressor cells. Cancer Res. 2011; 71:2664-74.

6. Tanaka T, Nishikawa A, Mori Y, Morishita Y, Mori H. Inhibitory effects of non-steroidal anti-inflammatory drugs, piroxicam and indomethacin on 4-nitroquinoline 1-oxideinduced tongue carcinogenesis in male $\mathrm{ACI} / \mathrm{N}$ rats. Cancer Lett. 1989; 48:177-82.

7. Wakimoto N, Wolf I, Yin D, O'Kelly J, Akagi T, Abramovitz L, Black KL, Tai HH, Koeffler HP. Nonsteroidal anti-inflammatory drugs suppress glioma via 15-hydroxyprostaglandin dehydrogenase. Cancer Res. 2008; 68:6978-86.

8. Li P, Wu H, Zhang H, Shi Y, Xu J, Ye Y, Xia D, Yang J, Cai $\mathrm{J}, \mathrm{Wu}$ Y. Aspirin use after diagnosis but not prediagnosis improves established colorectal cancer survival: a metaanalysis. Gut. 2015; 64:1419-25.

9. Wang WH, Huang JQ, Zheng GF, Lam SK, Karlberg J, Wong BC. Non-steroidal anti-inflammatory drug use and the risk of gastric cancer: a systematic review and metaanalysis. J Natl Cancer Inst. 2003; 95:1784-91. 
10. Mahmud SM, Franco EL, Aprikian AG. Use of nonsteroidal anti-inflammatory drugs and prostate cancer risk: a metaanalysis. Int J Cancer. 2010; 127:1680-91.

11. Luo T, Yan HM, He P, Luo Y, Yang YF, Zheng H. Aspirin use and breast cancer risk: a meta-analysis. Breast Cancer Res Treat. 2012; 131:581-7.

12. Scheurer ME, El-Zein R, Thompson PA, Aldape KD, Levin VA, Gilbert MR, Weinberg JS, Bondy ML. Long-term antiinflammatory and antihistamine medication use and adult glioma risk. Cancer Epidemiol Biomarkers Prev. 2008; 17:1277-81.

13. Sorensen HT, Friis S, Norgard B, Mellemkjaer L, Blot WJ, McLaughlin JK, Ekbom A, Baron JA. Risk of cancer in a large cohort of nonaspirin NSAID users: a population-based study. Br J Cancer. 2003; 88:1687-92.

14. Friis S, Sorensen HT, McLaughlin JK, Johnsen SP, Blot WJ, Olsen JH. A population-based cohort study of the risk of colorectal and other cancers among users of low-dose aspirin. Br J Cancer. 2003; 88:684-8.

15. Cook NR, Lee IM, Gaziano JM, Gordon D, Ridker PM, Manson JE, Hennekens CH, Buring JE. Low-dose aspirin in the primary prevention of cancer: the Women's Health Study: a randomized controlled trial. JAMA. 2005; 294:47-55.

16. Sivak-Sears NR, Schwartzbaum JA, Miike R, Moghadassi $\mathrm{M}$, Wrensch M. Case-control study of use of nonsteroidal antiinflammatory drugs and glioblastoma multiforme. Am J Epidemiol. 2004; 159:1131-9.

17. Daugherty SE, Moore SC, Pfeiffer RM, Inskip PD, Park Y, Hollenbeck A, Rajaraman P. Nonsteroidal anti-inflammatory drugs and glioma in the NIH-AARP Diet and Health Study cohort. Cancer Prev Res (Phila). 2011; 4:2027-34.

18. Scheurer ME, Amirian ES, Davlin SL, Rice T, Wrensch M, Bondy ML. Effects of antihistamine and anti-inflammatory medication use on risk of specific glioma histologies. Int J Cancer. 2011; 129:2290-6.

19. Gaist D, Garcia-Rodriguez LA, Sorensen HT, Hallas J, Friis $\mathrm{S}$. Use of low-dose aspirin and non-aspirin nonsteroidal anti-inflammatory drugs and risk of glioma: a case-control study. Br J Cancer. 2013; 108:1189-94.

20. Bannon FJ, O'Rorke MA, Murray LJ, Hughes CM, Gavin AT, Fleming SJ, Cardwell CR. Non-steroidal antiinflammatory drug use and brain tumour risk: a case-control study within the Clinical Practice Research Datalink. Cancer Causes Control. 2013; 24:2027-34.

21. Ferris JS, McCoy L, Neugut AI, Wrensch M, Lai R. HMG CoA reductase inhibitors, NSAIDs and risk of glioma. Int J Cancer. 2012; 131:E1031-7.

22. Seliger C, Ricci C, Meier CR, Bodmer M, Jick SS, Bogdahn U, Hau P, Leitzmann MF. Diabetes, use of antidiabetic drugs, and the risk of glioma. Neuro Oncol. 2016; 18:340-9.

23. Seliger C, Meier CR, Becker C, Jick SS, Bogdahn U, Hau P, Leitzmann MF. Use of Selective Cyclooxygenase-2 Inhibitors, Other Analgesics, and Risk of Glioma. PLoS One. 2016; 11:e0149293.
24. Liu Y, Lu Y, Wang J, Xie L, Li T, He Y, Peng Q, Qin X, Li S. Association between nonsteroidal anti-inflammatory drug use and brain tumour risk: a meta-analysis. Br J Clin Pharmacol. 2014; 78:58-68.

25. Sareddy GR, Geeviman K, Ramulu C, Babu PP. The nonsteroidal anti-inflammatory drug celecoxib suppresses the growth and induces apoptosis of human glioblastoma cells via the NF-kappaB pathway. J Neurooncol. 2012; 106:99-109.

26. Sharma V, Dixit D, Ghosh S, Sen E. COX-2 regulates the proliferation of glioma stem like cells. Neurochem Int. 2011; 59:567-71.

27. Kardosh A, Blumenthal M, Wang WJ, Chen TC, Schonthal AH. Differential effects of selective COX-2 inhibitors on cell cycle regulation and proliferation of glioblastoma cell lines. Cancer Biol Ther. 2004; 3:55-62.

28. Suzuki K, Gerelchuluun A, Hong Z, Sun L, Zenkoh J, Moritake T, Tsuboi K. Celecoxib enhances radiosensitivity of hypoxic glioblastoma cells through endoplasmic reticulum stress. Neuro Oncol. 2013; 15:1186-99.

29. Ma HI, Chiou SH, Hueng DY, Tai LK, Huang PI, Kao CL, Chen YW, Sytwu HK. Celecoxib and radioresistant glioblastoma-derived $\mathrm{CD} 133+$ cells: improvement in radiotherapeutic effects. Laboratory investigation. J Neurosurg. 2011; 114:651-62.

30. Kuipers GK, Slotman BJ, Wedekind LE, Stoter TR, Berg J, Sminia P, Lafleur MV. Radiosensitization of human glioma cells by cyclooxygenase-2 (COX-2) inhibition: independent on COX-2 expression and dependent on the COX-2 inhibitor and sequence of administration. Int J Radiat Biol. 2007; 83:677-85.

31. Petersen C, Petersen S, Milas L, Lang FF, Tofilon PJ. Enhancement of intrinsic tumor cell radiosensitivity induced by a selective cyclooxygenase- 2 inhibitor. Clin Cancer Res. 2000; 6:2513-20.

32. Kosaka A, Ohkuri T, Okada H. Combination of an agonistic anti-CD40 monoclonal antibody and the COX-2 inhibitor celecoxib induces anti-glioma effects by promotion of type1 immunity in myeloid cells and T-cells. Cancer Immunol Immunother. 2014; 63:847-57.

33. Robison NJ, Campigotto F, Chi SN, Manley PE, Turner CD, Zimmerman MA, Chordas CA, Werger AM, Allen JC, Goldman S, Rubin JB, Isakoff MS, Pan WJ, et al. A phase II trial of a multi-agent oral antiangiogenic (metronomic) regimen in children with recurrent or progressive cancer. Pediatr Blood Cancer. 2014; 61:636-42.

34. Wagemakers M, van der Wal GE, Cuberes R, Alvarez I, Andres EM, Buxens J, Vela JM, Moorlag H, Mooij JJ, Molema G. COX-2 Inhibition Combined with Radiation Reduces Orthotopic Glioma Outgrowth by Targeting the Tumor Vasculature. Transl Oncol. 2009; 2:1-7.

35. Eberstal S, Fritzell S, Sanden E, Visse E, Darabi A, Siesjo P. Immunizations with unmodified tumor cells and simultaneous COX-2 inhibition eradicate malignant 
rat brain tumors and induce a long-lasting CD8(+) T cell memory. J Neuroimmunol. 2014; 274:161-7.

36. Zhang H, Tian M, Xiu C, Wang Y, Tang G. Enhancement of antitumor activity by combination of tumor lysate-pulsed dendritic cells and celecoxib in a rat glioma model. Oncol Res. 2013; 20:447-55.

37. Eberstal S, Sanden E, Fritzell S, Darabi A, Visse E, Siesjo P. Intratumoral COX-2 inhibition enhances GM-CSF immunotherapy against established mouse GL261 brain tumors. Int J Cancer. 2014; 134:2748-53.

38. Stroup DF, Berlin JA, Morton SC, Olkin I, Williamson GD, Rennie D, Moher D, Becker BJ, Sipe TA, Thacker SB. Meta-analysis of observational studies in epidemiology: a proposal for reporting. Meta-analysis Of Observational Studies in Epidemiology (MOOSE) group. JAMA. 2000; 283:2008-12.
39. Stang A. Critical evaluation of the Newcastle-Ottawa scale for the assessment of the quality of nonrandomized studies in meta-analyses. Eur J Epidemiol. 2010; 25:603-5.

40. Xu C, Zeng XT, Liu TZ, Zhang C, Yang ZH, Li S, Chen $\mathrm{XY}$. Fruits and vegetables intake and risk of bladder cancer: a PRISMA-compliant systematic review and dose-response meta-analysis of prospective cohort studies. Medicine (Baltimore). 2015; 94:e759.

41. Orsini N, Li R, Wolk A, Khudyakov P, Spiegelman D. Metaanalysis for linear and nonlinear dose-response relations: examples, an evaluation of approximations, and software. Am J Epidemiol. 2012; 175:66-73.

42. Durrleman S, Simon R. Flexible regression models with cubic splines. Stat Med. 1989; 8:551-61. 